\title{
KEYNES VERSUS HAYEK: ON THE APPROPRIATENESS OF GOVERNMENT INTERVENTION IN MARKETS
}

\author{
HÜKÜMETIN PIYYASALARA MÜDAHALESININN UYGUNLUĞU \\ ÜZERINE: KEYNES - HAYEK'E KARŞI
}

\author{
Mehmet Levent YILMAZ \\ Hüseyin Atakan KESKINN**
}

\begin{abstract}
In keeping with the pattern of the last century, today we observe staunch and oftentimes vociferous opposition to even the prospect of state intervention in the market place to either curtail recessionary downturns or mitigate the corollaries of market failure. To whom or to what is this knee-jerk revulsion to government interference attributable? Is it justified? And what is the role of government in the contemporary economy? Figures that have dominated this hemisphere of thought include free-market advocates such as Friedrich von Hayek. On the other end of the spectrum, personalities like John Maynard Keynes challenged fundamentally the idea that market economies will automatically adjust to create full employment, in the process setting the parameters of a debate that rages on into the contemporary era.

Keywords: John Maynard Keynes, Friedrich Von Hayek, State Intervention In The Market Place, Free-Market, Keynesian Theory

JEL Codes: E12, E61, G18

Öz

Geçen yüzyılın kalıplarına uygun olarak bugün, durgunluk dönemindeki durgunlukları azaltmak ya da piyasa başarısızlığının korelasyonlarını hafifletmek için pazar alanına devlet müdahalesi ihtimaline bile zaman zaman güçlü ve muhtelif muhalefet izliyoruz. Hükümet tarafından yapılan müdahalelere atıfta bulunan bu tepki kim veya ne üzerine olabilir? Bu muhalefet haklı mı? Ve devletin çağdaş ekonomideki rolü nedir? $\mathrm{Bu}$ yarımküresel düşünceye egemen olan isimler, Friedrich von Hayek gibi serbest piyasa savunucularıdır.

* Dr. Öğr. Üyesi Mehmet Levent YILMAZ, Polis Akademisi Güvenlik Bilimleri Enstitüsü, Güvenlik Stratejileri ve Yönetimi Anabilimdalı, e-posta: mehmetlevent.yilmaz@pa.edu.tr

** Hüseyin Atakan KESKIN, Vice President, North America, The Roosevelt Group, USA, h.atakankeskin@gmail.com
\end{abstract}


Yelpazenin diğer ucunda, John Maynard Keynes gibi kişilikler, çağdaş döneme giren tartışmaların parametrelerini belirleyen süreçte, pazar ekonomilerinin otomatik olarak tam istihdam yaratmaya yönelecekleri fikrine meydan okudu.

Anahtar Kelimeler: John Maynard Keynes, Friedrich Von Hayek, Pazar Alanına Devlet Müdahalesi, Serbest Piyasa ,Keynesyen Teori

JEL Kodları: E12, E61, G18

\section{The Great Debate}

The "State v. Market" emerged from the chaos of the Great Depression in the 1930s where existing economic theory was unable either to explain the causes of the severe worldwide economic collapse or to provide an adequate public policy solution to jump-start production and employment. On the pro-intervention side of the gradient, British economist John Maynard Keynes spearheaded a revolution in economic thinking that overturned the then-prevailing idea that free markets would automatically provide full employment-that is, that everyone who wanted a job would have one as long as workers were flexible in their wage demands. The main pillar of Keynes's theory, which has come to bear his name, is the assertion that aggregate demand-measured as the sum of spending by households, businesses, and the government-is the most important driving force in an economy (Hans, 2008, p.4). Keynes further asserted that free markets have no self-balancing mechanisms that lead to full employment.

Keynes argued that inadequate overall demand could lead to prolonged periods of high unemployment. An economy's output of goods and services is the sum of four components: consumption, investment, government purchases, and net exports (the difference between what a country sells to and buys from foreign countries). Any increase in demand has to come from one of these four components. But during a recession, strong forces often dampen demand as spending goes down. For example, during economic downturns uncertainty often erodes consumer confidence, causing them to reduce their spending, especially on discretionary purchases like a house or a car. This reduction in spending by consumers can result in less investment spending by businesses, as firms respond to weakened demand for their products. This puts the task of increasing output on the shoulders of the government.

According to Keynes, state intervention is necessary to moderate the booms and busts in economic activity, otherwise known as the business cycle. Rather than seeing unbalanced government budgets as wrong, Keynes advocated so-called countercyclical fiscal policies that act against the direction of the business cycle. Over the next century, Keynesian economists would advocate deficit spending on labor-intensive infrastructure projects to stimulate employment and stabilize wages during economic downturns (Hans, 2008, pp.4-5). They would raise taxes to cool the economy and prevent inflation when there is abundant demand-side growth. Monetary policy could also be used to stimulate the economy-for example, by reducing interest rates to encourage 
investment. The exception occurs during a liquidity trap, when increases in the money stock fail to lower interest rates and, therefore, do not boost output and employment.

Keynes-a truly revolutionary mind-argued that governments should solve problems in the short run rather than wait for market forces to fix things over the long run, because, as he wrote, "In the long run, we're all dead." Even though Keynes' ideas were widely accepted while he was alive, they were also scrutinized and contested by several contemporary thinkers. Particularly noteworthy were his arguments with the Austrian School of Economics, whose adherents believed that recessions and booms are a part of the natural order and that government intervention only worsens the recovery process.

The Austrian dissenter from the growing consensus around Keynes was Friedrich von Hayek, an economist from Vienna. His book the "Road to Serfdom" argued that the extension of central planning is the start of the growth of constraints on individual liberty, which inevitably leads to the emergence of tyrannical regimes, both communist and fascist in nature. It was the culmination of four years' work - and several decades challenging many of Keynes' new economic theories, particularly on what governments should do during depressions. Hayek believed the economic system was "organic" and its stocks and flows trend towards producing good health, effective operation, and healing processes; automatically seeking correction and resolution of imbalances and perturbations without any government regulation or external influence (Hayek, 2014, p.26).

Hayek, in the 1970s, came to be seen as opposing everything Keynes and the Keynesian consensus stood for. More recently, many see the change towards more free-market ideas since the 1980 s as the victory of Hayek's ideas over Keynes - a trend that has seen a reversal since the Great Recession of 2008.

These two distinct economic camps-Keynesian and Austrian-have been a driving force in the U.S. economy since the end of World War II. Keynesian economics dominated economic theory and policy after World War II until the 1970s, when many advanced economies suffered both inflation and slow growth, a condition dubbed "stagflation." Keynesian theory's popularity waned then because it had no appropriate policy response for stagflation. Monetarist economists doubted the ability of governments to regulate the business cycle with fiscal policy and argued that judicious use of monetary policy (essentially controlling the supply of money to affect interest rates) could alleviate the crisis. Members of the monetarist school also maintained that money can have an effect on output in the short run but believed that in the long run, expansionary monetary policy leads to inflation only. Keynesian economists largely adopted these critiques, adding to the original theory a better integration of the short and the long run and an understanding of the long-run neutrality of money-the idea that a change in the stock of money affects only nominal variables in the economy, such as prices and wages, and has no effect on real variables, like employment and output.

Both Keynesians and monetarists came under scrutiny with the rise of the new classical school during the mid-1970s. The new classical school asserted that policymakers are ineffective 
because individual market participants can anticipate the changes from a policy and act in advance to counteract them. A new generation of Keynesians that arose in the 1970s and 1980s argued that even though individuals can anticipate correctly, aggregate markets may not clear instantaneously; therefore, fiscal policy can still be effective in the short run.

The global financial crisis of 2007-08 caused a resurgence in Keynesian thought. It was the theoretical underpinnings of economic policies in response to the crisis by many governments, including in the United States and the United Kingdom. As the global recession was unfurling in late 2008, Harvard professor N. Gregory Mankiw wrote in the New York Times:

If you were going to turn to only one economist to understand the problems facing the economy, there is little doubt that the economist would be John Maynard Keynes. Although Keynes died more than a half-century ago, his diagnosis of recessions and depressions remains the foundation of modern macroeconomics. Keynes wrote, 'Practical men, who believe themselves to be quite exempt from any intellectual influence, are usually the slave of some defunct economist.' In 2008, no defunct economist is more prominent than Keynes himself.

But the 2007-08 crisis also showed that Keynesian theory had to better include the role of the financial system. Keynesian economists are rectifying that omission by integrating the real and financial sectors of the economy.

\section{Business Cycle Fluctuations}

In their seminal study, Burns and Mitchell (1946) offer the following definition of the business cycle:

A cycle consists of expansions occurring at about the same time in many economic activities, followed by similarly general recessions, contractions, and revivals which merge into the expansion phase of the next cycle; this sequence of changes is recurrent but not periodic; in duration business cycles vary from more than one year to ten or twelve years; they are not divisible into shorter cycles of similar character with amplitudes approximating their own. (Burns and Mitchell, 1946, pp.24-26)

The above definition of the business cycle is well-established and principally not contentious; however, that is not to say that there are not competing explanations for why this seemingly cyclical economic trend occurs and how we ought to respond to it. Several theories of business cycles have been propounded from time to time. Each of these theories spells out the factors which cause business cycles. Before explaining the modern theories of business cycles we first explain below the earlier theories of business cycles as they too contain important elements whose study is essential for proper understanding of the causes of business cycles (Stock and Watson 1998; Pettinger 2017). 


\section{(i.) The Sun-Spot Theory}

This is perhaps' the oldest theory of business cycles. Sun-spot theory was developed in 1875 by Stanley Jevons. Sun-spots are storms on the surface of the sun caused by violent nuclear explosions there. Jevons argued that sun-spots affected weather on the earth. Since economies in the olden world were heavily dependent on agriculture, changes in climatic conditions due to sunspots produced fluctuations in agricultural output. Changes in agricultural output through its demand and input-output relations affect industry. Thus, swings in agricultural output spread throughout the economy (Jevons, 1875, pp.194-205).

Other earlier economists also focused on changes in climatic or weather conditions in addition to those caused by sun-spots. According to them, weather cycles cause fluctuations in agricultural output which in turn cause instability in the whole economy. Even today weather is considered important in a country like India where agriculture is still important. In the years when due to lack of monsoon there are drought in the Indian agriculture, it affects the income of farmers and therefore reduce demand for the products of industries. This causes industrial recession. Even in USA in the year 1988 a severe drought in the farm belt drove up the food prices around the world. It may be further noted that higher food prices reduce income available to be spent on industrial goods.

Though the theories of business cycles which emphasize climatic conditions for business cycles contain an element of truth about fluctuations in economic activity, especially in the developing counties like India where agriculture still remains important, they do not offer an adequate explanation of business cycles. Therefore, much reliance is not placed on these theories by modern economists. Nobody can say with certainty about the nature of these sun-spots and the degree to which they affect rain. There is no doubt that climate affects agricultural production, but the climate theory does not adequately explain periodicity of the trade cycle. If there was truth in the climatic theories, the trades cycles may be pronounced in agricultural countries and almost disappear when the country becomes completely industrialized. But this is not the case. Highly industrialized countries are much more subject to business cycles than agricultural countries which are affected more by famines rather than business cycles. Hence variations in climate do not offer complete explanation of business cycles.

\section{(ii.) Hawtrey's Monetary Theory of Business Cycles'}

An old monetary theory of business cycles was put forward by British economist Ralph Hawtrey. His monetary theory of business cycles relates to an economy which is under a gold standard, when either money in circulation consists of gold coins or when paper notes are fully backed by gold reserves in the banking system.

According to Hawtrey, increases in the quantity of money raise the availability of bank credit for investment. Thus, by increasing the supply of credit, interest rates fall. The lower rate of interest induces businessmen to borrow more for investment. Hawtrey essentially argues that a lower rate of interest will lead to the expansion of goods and services as a result of more investment in 
capital goods and inventories. This effect is augmented by higher output, income, and employment that results from more investment inducing spending on consumer goods (Hayek, 1933, pp.141-150).

However, according to Hawtrey, the expansion process must end. He argued that a rise in incomes during the expansion phase induces more expenditure on domestically produced goods as well as more on imports of foreign goods. He further assumes that domestic output and income expand faster than foreign output. As a result, imports of a country increase more than its exports causing a trade deficit with other countries. If the exchange rate remains fixed, a trade deficit means there will be an outflow of gold to settle an economy's balance of payment deficit. Since the country in question is under a gold standard, the outflow of gold will cause a reduction in money supply in the economy. The decrease in money supply will reduce the availability of bank credit. Reduction in the supply of bank credit will cause the rate of interest to rise. Rising interest rates will reduce investment in physical capital goods. Reduction in investment will cause the process of contraction to set in.

After a lapse of sometime, this contraction will come to an end and the economy will start to recover. This happens because in the contraction process imports fall drastically due to a decrease in income and consumption of households, whereas exports do not fall much. As a result, a trade surplus emerges which causes an inflow of gold. The inflow of gold would lead to the expansion of the money supply and consequently the availability of bank credit. With this, the economy will recover from depression and move into the expansion phase. Thus, the cycle is complete. The process, according to Hawtrey, will go on being repeated regularly (Hayek, 1933, pp.147-149).

The problem with Hawtrey's monetary theory is that it does not apply to the present-day economies which have abandoned the gold standard of the 1930s. Nevertheless, Hawtrey's theory still retains its importance because it shows how changes in money supply affect economic activity through changes in price level and rate of interest. This relationship between money supply and rate of interest plays an important role in determining levels of economic activity.

\section{(iii.) Under-Consumption Theory}

The Under-consumption theory of business cycles is one which dates back to the 1930s. The basis of this theory can be traced back to Thomas Malthus and Jean Sismondi's criticism of Say's Law, which states 'supply creates its own demand.' They argued that consumption of goods and services could be too small to generate sufficient demand for goods and services produced. They attribute over-production of goods due to lack of consumption demand for those goods. This over-production causes a piling up of inventories which precipitates recession (Subho 2008, http://www.economicsdiscussion.net/, 12 November 2017).

A crucial aspect of under-consumption theory is the distinction they made between the rich and the poor. According to them, the wealthy sections of a society receive a large part of their income from returns on financial assets and real property. Further, they assume that the rich have a 
large propensity to save, that is, they save a relatively large proportion of their income and therefore, consume a relatively smaller proportion of their income. On the other hand, less well-off people in a society obtain most of their income from work, that is, wages from labor and have a lower propensity to save. In their theory, they further assume that during the expansion process, the incomes of the rich increase relatively more than the wage-income. Thus, during the expansion phase, income distribution changes in favor of the rich and therefore consumption demand declines, halting economic expansion (Subho 2008, http://www.economicsdiscussion.net/, 12 November 2017).

Moreover, since the supply of goods increases more than consumption demand for them, prices fall. Prices continue falling and go even below the average cost of production. As a result, when under-consumption emerges, production of goods becomes unprofitable. Firms cut their production resulting in recession or contraction in economic activity.

The view that income inequalities increase with growth or expansion of the economy and further that this causes recession or stagnation is widely accepted. Therefore, even many modern economies suggest that if growth is to be sustained (that is, if recession or stagnation is to be avoided), then consumption demand must be increasing sufficiently to absorb the increasing production of goods. For this deliberate efforts should be made to reduce inequalities in income distribution. Further, under-consumption theory rightly states that income redistribution schemes will reduce the amplitude of business cycles.

\section{(iv.) Hayek's Monetary Version of Over-investment Theory}

Hayek suggests that it is monetary forces which cause fluctuations in investment which are the principal cause of business cycles. In this respect, Hayek's theory is similar to Hawtrey's monetary theory except that it does not involve the inflow and outflow of gold (Hayek, 1933, pp.148-150).

To begin with, let us assume that the economy is in recession and demand for bank credit is very low. Lower demand for bank credit in times of recession push down the money rate of interest below the natural rate. This means that businessmen will be able to borrow funds at a rate of interest which is below the expected rate of return in investment projects. This induces them to invest more by undertaking new investment projects. In this way, investment expenditure on new capital goods increases. This causes investment to exceed saving by the amount of newly created bank credit. With the spurt in investment expenditure, the expansion of the economy begins. Increase in investment causes income and employment to rise which induces more consumption expenditure. As a result, production of consumer goods increases (Deardorff, 2010, pp.8-9).

However, this process of expansion cannot go on indefinitely because the excess reserves with the banks come to an end, which forces the banks not to give further loans for investment, while demand for bank credit goes on increasing. Thus, the inelastic supply of credit from the banks and mounting demand for it causes the money rate of interest to go above the natural rate. This makes further investment unprofitable. When no more bank credit is available for investment, 
there is a decline in investment, which causes both income and consumption to fall and in this way expansion comes to an end and the economy experiences a contraction.

After a lapse of sometime, the fall in demand for bank credit lowers the money rate of interest which goes below the natural rate of interest. This, again, gives a boost to investment activity and, as a result, the recession ends.

Though the over-investment theory does not offer an adequate explanation of business cycles, it contains an important element that fluctuations in investment are important in the study of business cycles. It does not, however, offer a valid explanation as to why changes in investment take place as often as they do. Keynes would later emphasize that investment fluctuates quite often because of changes in the profit expectations of entrepreneurs, which depends on several economic and political factors.

\section{The Role of Government in the Contemporary Economy}

Ideological debates on the role of government have focused on two contrasting prescriptions: one calling for large scale government interventions to solve problems of massive market failures, the other for the unfettering of markets, with the dynamic forces of capitalism naturally leading to growth and prosperity; however, the global financial crisis forced a rethinking of many basic precepts within conventional international policy circles: markets evidently were not on their own either efficient or stable; and self-regulation did not suffice. Of course, many of these notions were not really new: they were lessons learned in the Great Depression, and relearned in the East Asian crisis and in the many other crises that have afflicted the global economy since the beginning of the era of deregulation in the early 1980s.

For emerging markets, the instability in cross-border capital flows has been particularly troublesome. A large fraction of the crises these countries face arise as a result of volatility in international capital markets, including those brought about by the creation and breaking of credit and housing bubbles in developed countries-and not in the emerging market countries themselves. The global financial crisis, which brought such havoc on the global economy, as a result of the failure of the US to manage its financial system, is the example par excellence. Of course, some less developed countries and emerging markets will be more vulnerable than others, including those with large trade and fiscal deficits. Nevertheless, the shock to the economy can be clearly identified as originating from outside its borders Given this, it is reasonable that countries take actions to protect themselves, to limit their exposure to these risks. That is what capital account management is all about. It is, of course, broader than just the management of exposure to aggregate risks, and it can take many forms. It may include restrictions on derivatives, those instruments of financial mass destruction. It may include restrictions on capital inflows (as in Chile or Colombia), or, especially in times of crises, on capital outflows. It may include restrictions on foreign exchange exposure of banks. Government interventions may entail price or quantity restrictions. While economists have long had a predilection for the former, research over the past 30 years has shown that "controls" may be superior to "taxes" in the presence of pervasive uncertainties, 
such as those that afflict financial markets (Stiglitz, 2013, https://www.globalcapital.com/article/ yvxs2x0rgb82/joseph-stiglitz-government-intervention-is-desirable, 13 November 2017).

The reason that government intervention is desirable is simple: there are large macroeconomic externalities associated with these capital flows. They can result in exchange rate fluctuations, imposing large costs on exporters and importers. In the extreme, they can trigger crises like the East Asian crisis, with prolonged economic and social damage. Government attempts to mitigate these fluctuations or to respond to their consequences may involve enormous costs. For instance, in the East Asia crisis, to stabilize the exchange rate, most countries raised interest rates, in some cases to astronomical levels, forcing many firms within these countries into bankruptcy. These firms bore the costs of others' unbridled foreign borrowing. Additionally, many governments built up huge war chests of reserves in response to the crisis. This had a huge opportunity cost, even if it limited some risks. Most countries hold these reserves in T-bills, earning negative real interest rates, when within their countries there are innumerable investments yielding far higher real returns. Still, the price of holding reserves was worth paying, given the instability caused by unfettered global capital markets. Yet these other costs are not taken into account-either by individuals and firms within a country, in making borrowing decisions, or foreign short-term investors, in making investment decisions (Stiglitz, 2013, https://www.globalcapital.com/article/ yvxs2x0rgb82/joseph-stiglitz-government-intervention-is-desirable, 13 November 2017).

\section{Keynes or Hayek?}

The global economy is failing to thrive, and its caretakers are fumbling. Greece took its medicine as instructed and was rewarded with an unemployment rate of 26 percent. Portugal obeyed the budget rules; its citizens are looking for jobs in Angola and Mozambique because there are so few at home. Germans are feeling anemic despite their massive trade surplus. In the U.S., the income of a median household adjusted for inflation is 3 percent lower than at the worst point of the 2007-09 recession, according to Sentier Research. Whatever medicine is being doled out isn't working. Citigroup Chief Economist Willem Buiter recently described the Bank of England's policy as "an intellectual potpourri of factoids, partial theories, and empirical regularities without firm theoretical foundations, hunches, intuitions, and half-developed insights." And that, he said, is better than things countries are trying elsewhere (BBC, 2011, https://www.bbc.com/news/business-14366054, 17 November 2017).

John Maynard Keynes has more to teach us about how to save the global economy than an army of modern Ph.Ds. equipped with models of dynamic stochastic general equilibrium. The symptoms of the Great Depression that he correctly diagnosed are back, though fortunately on a smaller scale: chronic unemployment, deflation, currency wars, and beggar-thy-neighbor economic policies. The big question is whether today's international financial architecture is up to the challenge of restoring balance to global trade and investment. The IMF, to its credit, has pivoted away from the austere prescriptions of the "Washington Consensus" that it championed through the 1990s and toward a more Keynesian perspective. "His thinking is more relevant at the current juncture than it had been in previous troughs of the global economy," says Gian Maria 
Milesi-Ferretti, deputy director of the IMF's research department (Jahan, Papageorgiou, 2014 and Jahan, Mahmud, Papageorgiou 2014).

So goes the fighting among the physicians as the patient ails. Keynes saw the same kind of flailing at the start of the Depression. "We have involved ourselves in a colossal muddle, having blundered in the control of a delicate machine, the working of which we do not understand," he wrote in 1930. "The result is that our possibilities of wealth may run to waste for a time-perhaps for a long time." Keynes himself has shown us the way out.

\section{Conclusion}

In short, Keynes took the lessons of Hayek's work as a warning that the expansion of state should be limited and politicians need to know when to stop-which he fundamentally agreed with. Although he thought more state control in some areas may be justified, governments always need to demark a line beyond which they do not traverse. That may be a lesson not only relevant for then, but also for our time as well.

The profession of economics is replete with contention and discord amongst its various schools of thought; however, none seem as diametrically opposed as the Austrians and the Keynesians, both personified by the figures of Friedrich von Hayek and John Maynard Keynes respectively. The debate over whether or not the government has a role to play in halting economic downturns during the recessionary period of a business cycle still continues and will likely persist into the foreseeable future, though the evidence that we have acquired from the data imply that the government ought not to remain idle in times of severe economic distress and should proactively utilize all of its tools, in the form of fiscal and monetary policy, to adequately address temporary ailments before they become permanent scars. Nonetheless, the names of both John Maynard Keynes and Friedrich von Hayek will forever be etched into the annals of history.

\section{Bibliography}

BURNS, Arthur, F., MITCHELL, Wesley C., "Measuring Business Cycles" (1946). National Bureau of Economic Research, ISBN: 0-870-14085-X.

BEAUDRY, Paul, GALIZIA, Dana and PORTIER, Franck. (2017) "Reconciling Hayek's And Keynes Views Of Recessions." Review of Economic Studies, 1-38.

DEARDORFF, Alan V. (2000). “The Economics Of Government Market Intervention, And Its International Dimension.” Research Seminar In International Economics, University of Michigan.

HANS, V. Basil. (2014). "State And The Market - Debate And Developments." SSRN, E-Journal, January 2, 2014.1-12.

JAHAN, Sarwat, Chris PAPAGEORGIOU. (2014). "What Is Monetarism? - Back To Basics" IMF, Finance \& Development, Vol 51, No 1. March.1-2.

JAHAN, Sarwat, MAHMUD, Ahmed Saber and Chris PAPAGEORGIOU. (2014). "What Is Keynesian Economics? - Back To Basics” IMF, Finance \& Development, Vol 51, No 3., September. 
JEVONS, William Stanley. “The Solar Period and the Price of Corn (1875)”. Investigations in Currency and Finance. London: Macmillan, 1909.

MANKIW, N. Gregory, "What Would Keynes Have Done?” (2008). The New York Times, 28 November. PETTINGER, Tejvan. (2017). “Causes Of Business Cycle.” Economics Help. Web. 10 November 2017.

STEFANO. Eusepi and PRESTON Bruce. (2011). "Expectations, Learning And Business Cycle Fluctuations." National Bureau Of Economic Research. American Economic Review, American Economic Association, vol. 101(6).

STIGLITZ, Joseph E. (2013). “The Global Financial Crisis has made capital account management more important than ever”. Global Capital. Web. 13 November 2017.

STOCK, James H. and WATSON, Mark W., (1998). "Business Cycle Fluctuations In Us Macroeconomics Times Series" National Bureau of Economic Resaarch, Cambridge.

SUBHO, Mukher. (2008). “4 Essential Theories of Business Cycles - Discussed!”. http://www.economicsdiscussion.net/, Web. 12 November 2017.

Von HAYEK, F. A., \& KALDOR, N. (1933). Monetary Theory and The Trade Cycle. London: Jonathan Cape.

Von HAYEK, F. A. (2014). The Road to Serfdom: Text and Documents: The Definitive Edition. Routledge. Original Printed April 1945 Edition.

\section{Internet Bibliography}

“Keynes V Hayek: Two Economic Giants Go Head To Head”. (2011). BBC News. Web. 11 November 2017.

"Prophets For Today." (2014) The Economist. The Economist Newspaper, 14 Mar. 2014. Web. 11 November 2017.

"What Is Austrian Economics?" (2017) Mises Institute. Web. 13. November 2017. 